\title{
China moves to help high-tech firms
}

Two initiatives to boost investment in high-tech companies in China have received a mixed response from entrepreneurs.

Trading in shares in the first 28 companies on ChiNext, a new stock exchange for innovation-oriented companies, started on 30 October. On the same day, the government's National Development and Reform Commission (NDRC) announced that it was creating 20 venture-capital funds that would be worth 9 billion renminbi (US $\$ 1.3$ billion), a significant proportion of the country's venturecapital market (see graphic).

ChiNext, part of the Shenzhen Stock Exchange (SZSE) in Shenzhen, is being called China's answer to the NASDAQ, the US market considered the natural home for high-tech businesses. On ChiNext's opening day, share prices on the SZSE grew so quickly that regulators were forced to suspend trading, fearing dangerous inflation of stock.

"[ChiNext] will speed up the establishment of spin-offs and provide an effective financing channel to commercialize technologies," says Li Yang, a project manager at the International Technology Transfer Center at Tsinghua University in Beijing, which has one of the strongest university intellectual-property portfolios in China.

Lawrence Lau, an economist and vice-chancellor of the Chinese University of Hong Kong, agrees that ChiNext is a positive development because it provides a convenient way to make money by issuing stocks in small Chinese companies, a channel that has not previously existed (see Nature 437, 1087; 2005).

Greg Scott, founder of the Shanghai-based

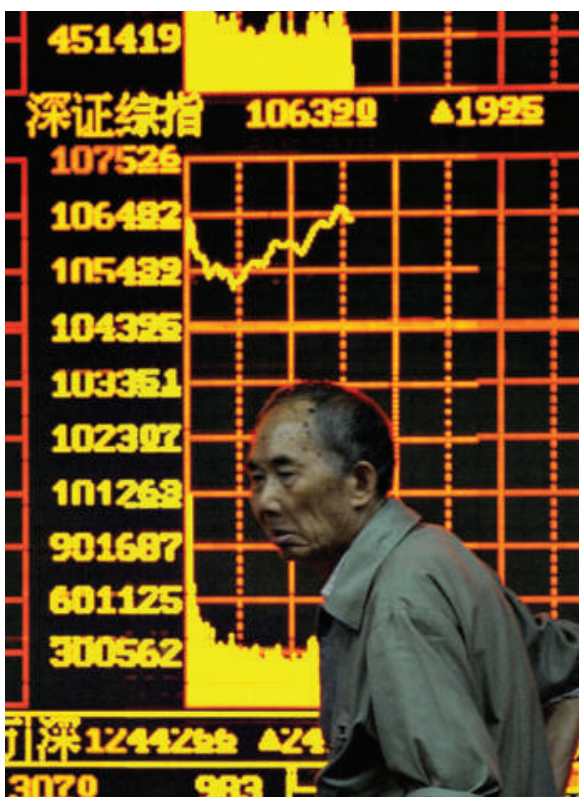

Shares in companies quoted on the new ChiNext stock exchange soared on the opening day.

consulting firm ChinaBio, points out that four of the five pharmaceutical companies listed on ChiNext are producing or planning to produce novel drugs. Until now, he says, most successful Chinese pharmaceutical companies have focused on medical devices or generic versions of existing drugs. "Seeing so many [innovative companies] in the drug space surprises me," adds Scott.

Tom Baruch, founder of CMEA Capital, based in San Francisco, California, says that the new market makes foreign investment in

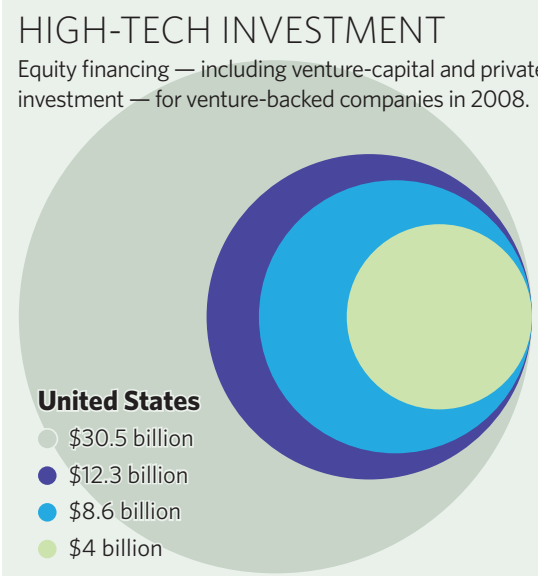

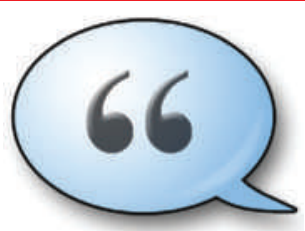

HAVE YOUR SAY

Comment on any of our

News stories, online.

www.nature.com/news
Chinese companies more likely. "I am sure there will be a great deal of foreign interest in the stocks listed on ChiNext," agrees Lau, "but China does not really need more foreign capital."

Some critics point out, however, that companies must clear significant hurdles before they can be listed. Businesses must show a cumulative profit of 10 million renminbi over the past two years, or a profit of 5 million renminbi in the past year with revenue of 50 million renminbi and a two-year revenue growth rate of at least $30 \%$.

That's difficult for most small, innovative companies in need of funding, says Qiang Yu, chief executive of Shanghai Ambrosia Pharmaceuticals. "The first companies [quoted on ChiNext] are not high tech and high risk; they are quite mature and profitable."

$\mathrm{Yu}$ and Mingdong Zhou, founder and chief executive of Zensun (Shanghai) Science \& Technology Ltd, have both struggled to raise funds to develop drug candidates, and they expect little help from the new market. "Domestic innovations are not the target of ChiNext," says Zhou. "There is virtually no financial mechanism to support innovative drug development in China, except for basic research." Clinical trials are particularly difficult to finance, he adds.

\section{No sea change}

Venture capital for small pharmaceutical and biotech companies has long been hard to come by in China, and some question whether the government's new fund will change that.

In the NDRC scheme, central government is providing 1 billion renminbi, and seven local governments are chipping in with a total of 1.2 billion renminbi. The rest of the 9-billion-renminbi fund is expected to come from private sources.

But little of the funding is likely to reach biotechs, predicts Scott, because the scheme relies so heavily on private investors, who are usually wary of long-term drug development.

"These funds are for a variety of technologies, including IT, electronics, energy and environment. I think life sciences will see very little - private investors much prefer the faster returns provided by the tech industries," he explains. "Only about $5 \%$ of venture-capital funding in China goes into life sciences. If you extrapolate that to the new funds, a total of about US\$64 million would end up in life sciences - helpful, but not a sea change." David Cyranoski 